\title{
A call for the restoration of orthodoxy in South African Christian theology
}

\author{
B Engelbrecht \\ University of the Witwatersrand
}

\begin{abstract}
A call for the restoration of orthodoxy in South African Christian theology
\end{abstract}

Liberation theology can only be understood as a pseudo-theology inspired by the spirit of Marx. It is not a bona fide or legitimate theology, but the polar opposite thereof. Its destructive aims mirror those of Marxism, which can only be understood if the demonic spirit of Marx is seen as its real origin. The Kairos Document and the Road to Damascus replaced the biblical God with the anti-god of Marx, the deified proletariat and the deified revolution. The article calls for a reconversion to God who revealed himself in Jesus Christ of Scriptures. Orthodox theology is truly 'thisworldly' theology, since it offers real hope and salvation. The Marxist gospel can only offer a utopia, a 'no-place'. It is self-alienating, world-alienating and God-alienating.

\section{'POLITISCHE THEOLOGIE'}

I had the opportunity some years ago - I can hardly call it a privilege - to get a glimpse into what I, on my part, would prefer to call the apocalyptic 'heresy', 'blasphemy' and 'apostasy' of our time, perhaps of the entire history of the Christian Church and of theology (cf Road 1990:10ff on idolatry, heresy, apostasy, hypocrisy and blasphemy). What I am referring to is, indeed, the interpretation and understanding of the Bible in the spirit of Karl Marx. Some of our late twentieth century

- This article was read as a paper at the annual conference of the Association for the Study of Religion in Southern Africa, July 1990, University of the Witwatersrand. 
theologians have discovered the gospel of the self-proclaimed world-saviour, Karl Marx, and, with undisguised exultation and surprise, they declare that at last the 'missing link' between the Scriptures and historical man has been found. Marx was the angel of God, the eldest son of Israel who presented the Church and Christian theology with the hermeneutical key to unlock the real, eternal and universal message of the Bible. ${ }^{1}$

My glimpse into this new theology - or real theology 'for the first time' in history 2 - resulted in a book written by me on German 'politische Theologie' or 'Theologie der Revolution' (Engelbrecht 1978:13ff). It was a fascinating experience. My encounter with this theology was like an encounter with an angry snake. I marvelled at its irresistible beauty and, at the same time, I experienced repulsion and abhorrence by its dangerous and deadly venom. I realised that it should be killed, destroyed, and I did throw a few stones at it, but knowing that a rock was needed for this, I decided - wisely, in my opinion - to retreat to the safety of the laager of my own traditional brand of 'right-wing' theology and Christian faith. 3

\section{LIBERATION THEOLOGY}

The highly sophisticated and dialectical 'politische Theologie' has its popularised counterpart in, inter alia, the South African liberation theology. But, whereas 'politische Theologie' has something fascinating about it, something both irresistibly attractive and, simultaneously, something unbearably repulsive, like the angry snake, South African liberation theology is, to the orthodox mind, a disgusting phenomenon. In as much as it claims to be theology and its literature to be theological literature, it deserves no other name than theological pornography. Yet, in spite of this, it serves the aims of Marx, the self-deified anti-god, better than he ever would have expected any other sort of popularisation of his ideals could have done.

Liberation theology is a theology for the masses, no longer the opium of the people, but far worse, it is a poisoned cup which, once it is taken, kills the souls of people - in the sense that they are transformed from the people of God, the Father of Jesus Christ, or potential people of God, to worshippers of the devil.

Liberation theology is doing exactly that which Jesus refused to do when He was tempted in the desert by the devil. It is an unconditional surrender to the claims of the devil which Jesus resisted. Whereas He, Jesus, recognised a satanic temptation in the suggestion that bread for the masses, the solution for the 'economic problem' was the main objective of his messianic mission - which would logically involve going down on his knees before Satan and a distortion of the Word of God from beginning to end - liberation theology urges us to accept this as the unique gospel (cf 
Matthew's recording of the temptation of Jesus by the devil, Mt 4:1-11).

\section{THE SPIRIT OF MARX}

Corruptio optimi pessima - the corruption of the good brings forth the worst. Everything infected with the ideas of the evil spirit of Marx, turns into something radically evil, whether it be politics, economics, social theory, philosophy, or religion and theology. In liberation theology we do not only see a corruption of theology but, in fact, its dismal destruction.

An evil passion for the destruction of the existing world and the totality of existing reality possessed the soul of Marx. ${ }^{4}$ He hated God, he hated himself, he hated the world. Yet in spite of his self-hatred, projected onto the totality of the world, he was also possessed by the idea that it was his calling to transform the world, to find a new God as a sort of a transcendent or numinous power with which he could captivate the world, and to found a new people, a new Israel for an exodus to another world, spurred on by the surrogate God whose being and power were hiddenly present in alienated man himself, and incarnate in Marx himself.

This new God who elected Marx to be the world-Saviour, is the power of a dialectic through which (contrary to Hegel) not the Absolute Spirit, or God, is realising himself, but through which God will ultimately and finally be dethroned. After all, there is no other God than man himself and in order to be exactly this, a god unto himself, man should discover his own latent power, God within himself, to work out his own salvation. 5

The evils of economic inequality, of private property, of some people being land and factory owners and other labourers, which are the basic causes of man's alienation, these are the effective causes of all miseries in the world. ${ }^{6}$ Marx's dialectic, in contrast to that of Hegel, is one in which alienated (but deified) man is solely responsible for realising a kingdom of freedom without God, a complete nova creatio emerging from a process in which the (deified) power of revolution and destruction is the propelling force. ${ }^{7}$

Marxism and its destructive effects can only be understood if the demonic spirit of Marx is seen as its real origin. Likewise, liberation theology can only be understood as a pseudo-theology inspired by the spirit of Marx. Despite its use of the Bible to justify its own destructive aims, or, to put it in the words of The Kairos Document, 'to develop...an alternative biblical and theological model that will in turn lead to forms of activity that will make a real difference to the future of our country', it is not bona fide or legitimate theology, but the polar opposite thereof. It is, in fact, an anti-theology intent upon replacing the biblical gospel with an anti- 
gospel, upon destroying the biblical gospel once and for all.

\section{THE 'ABOMINATION OF DESTRUCTION'}

It is not my intention, neither will it be possible in the time allotted for this paper, to deal with the problem of liberation theology as an anti-gospel in too much detail. I am of the opinion, however, that the few points I have selected will suffice to justify a call for the restoration of orthodoxy in present-day Christian theology in South Africa - a call which should not be left to me alone. To be sure, I can easily retreat on my own into the laager of orthodoxy where I find safety and protection of my faith amidst a cloud of witnesses. That which is being threatened and denied, beleaguered, mocked and accused, however, is the faith and message of the Christian Church as such.

It is the Christian Church itself, in our own country and elsewhere, which is to realise that the attack which is launched upon it is meant to destroy its very being, its truth, its reason for existence. It is the Body of Christ on earth which is challenged with, and already involved in a struggle of life and death with the incarnation and theologisation of the power of evil.

Perhaps the word 'evil' should as this point, for the sake of clarity, be explained

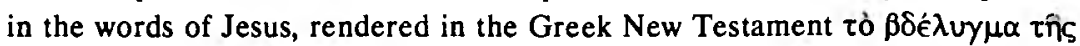

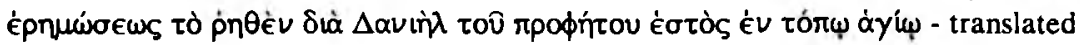
in the RSV into 'the desolating sacrilege spoken of by the prophet Daniel, standing in the holy place', and in Afrikaans and German, more literally, 'the abomination of destruction spoken of by the prophet Daniel, standing in the holy place' (Mt 24:15).

Evil in its deepest manifestation is to be understood as the abominable power of destruction, disguised as God himself, pretending to utter the words of God, but being possessed with a furious hatred against God, his creation, and his work of salvation. Theology inspired by the spirit of Marx is evil theology intent upon the destruction not only of orthodoxy, but also of all forms of order in the world and ultimately of the world and of creation itself, indeed, of God himself.

Consider the following:

\section{An alternative God?}

The Kairos Document and The Road to Damascus, which are to be regarded as the manifesto's of liberation theology in South Africa do not only proclaim 'an alternative biblical and theological model' on which the future of our country should be constructed, but also an altemative God to the God of traditional orthodox theology. 
The question: 'Who is God?' can never, and has never been fully fathomed, understood and explained. Even the Bible itself seems to guard and protect the mystery of God with something like a holy jealousy. God simply 'is who He is' (cf Ex 3:14). Paul Tillich made of this: God is 'Being-itself', although Tillich never tried either to explain or to prove God as 'Being-itself. Yet in this way of 'naming' God, he showed a deep respect for the mystery of God, his wholly-otherness, his being the unique Creator who 'lets being be', his distinct and essential difference from his creatures and from all 'beings' that have being.

I do not state here that Tillich is my model of Christian orthodoxy. For guidance with regard to orthodox reflection on the mystery of God, I would rather take recourse to some traditional confessions of the Church. Taking my position here, among a 'cloud of witnesses', I come to the conclusion that even Tillich, in spite of his experimental theology, his inventiveness and his innovations, approached the mystery of God with an awe and respect characteristic of the entire tradition of orthodox theology.

Awe and respect for the unfathomable mystery of God forbid us to locate God anywhere in time or space or even attempt to identify him. Yet we can confess our faith in Him who is, and in our confession we can also give expression to who we believe him to be. Our source of information in this regard is first and foremost the Bible, the Holy Scriptures, and in a secondary way, God's creation as it is seen in the light which is shed upon it by his revelation.

\section{God is Love}

Traditional Christian confessions are characterised by a profound modesty whenever attempts are made to express the 'who-ness' of God. In the Apostles' Creed He is simply called 'God, the Father, the Almighty, the Creator of heaven and earth'. As such He is the Trinitarian God, whose essence is love. The letting-be of being, says Tillich, is the highest form of love. The world and all reality 'is', because God is love.

The Christian confession insists, moreover, that God is unfailing love. The bond of love between the Creator and his creation is an indestructible one. The divine love is not a solution, but at least an unfolding of the mystery of God being the Trinitarian God, Father, Son and Holy Spirit. God the Creator remains in all eternity faithful to his creation because he is three-in-one. God who created will also redeem his world and he will also recreate this world so that in all eternity it will be the theatre of his glory.

Confessing this God is the sum total of biblical revelation: Being the Creator (the Father) the Redeemer of his creation (the Son) and the Re-creator of this very 
creation (the Holy Spirit), he is a superabundant Fountain of goodness and grace (cf Confessio Belgica, 1). Through man's fall into sin, which man himself intended and still intends not to be a fall but a hubristic appropriation for himself of selfdeification - sicut Deus eritis - the whole creation was plunged into the misery of doom and death.

\section{The mystery of history}

This is, and will be until the end of time, the scene of history. Yet God remains, and will remain in all eternity faithful to his creation. It is this scene of history, one of a radical alienation from its Maker and an equally radical demonisation of man, onto which God, whose essence is love, rushed in order to rescue, redeem and save it.

That is the reason why he called Abraham, Isaac and Jacob to enter into a covenant with them, why he elected Israel to be the bearer of his Torah and of his promises of salvation in the world, why the word and the promise of salvation became flesh in Jesus Christ. That is also the reason why, in a final, eschatological act of salvation, God will intervene to put an end to the destruction brought upon his creation by sin and evil. This world will be saved by virtue of his unfailing love for it. The last enemy to be destroyed will be death, the power of destruction itself (cf 1 Cor 15:26). This world will in all eternity remain the object of God's love.

Orthodox theology is, indeed, a 'this-worldly' theology, putting forward the biblical, 'this-worldly' gospel from beginning to end. Also, it is orthodox theology which presents us with some clues for the explanation - not the solution - of the mystery of history. It can be summed up in the words: Guilt and the reconciliation of guilt.

Moreover, in these few words the theme of the entire Bible is expressed and formulated. History is, for the orthodox theologian, that which the Bible says it is. It is the history into which God entered with a fallen world, in which the calling of Abraham, the election of Israel, the incarnation of the Word, the vicarious, sacrificial death of the Christ, his resurrection and ascension, and the outpouring of the Holy Spirit on Pentecost are the decisive moments.

\section{The role of man in God's history}

Of course, I have thus far only given some indications of what orthodox theology is about. It is, in its totality, a reflection on the biblical gospel which proclaims the complete salvation for the entire world from absolute perdition: Sola gratia through the amazing grace of God alone; to be appropriated sola fide - by faith alone; wrought by the sacrifice of Christ alone - solo Christo; proclaimed by the Word of God alone - solo verbo. However, these few indications and the emphasis 
on the belief that God alone is the Saviour of his creation, are necessarily to be supplemented with a brief reference to the role of man in the history of God.

It belongs to the glory bestowed upon man by God that he can act, and does act, as a co-worker of God. This is why God entrusted his Torah to Israel, and why the Torah remains valid, mutatis mutandis according to historical times and circumstances, in God's universal struggle to detect and hunt, to expose and judge evil in his world. This evil, however, can never be isolated nor can it be projected. The sanctifying work of man cum the Holy Spirit and the sanctifying struggle of man cum the Torah culminates, without exception, in the confession of every human being that 'I am guilty' not only of transgressing the law of God but, indeed, also of rejecting God.

\section{Sin and guilt}

Christ brought his sacrifice of redemption and reconciliation for sinners and for the guilty - only for them. There is no place for the righteous before the tribunal of God and of his crucified and resurrected Christ (Rm 3:10-18; cf Ps 14).

An affirmation of the basic message of the gospel, expressed in the recognition that the blood of Jesus Christ cleanses us from all sin (1 Jn 1:7), is at the same time an affirmation of God's radical judgement that the world and humanity in its entirety, without a single exception, are radically evil and corrupt. Only this state of affairs necessitated a divine intervention of such a radical nature, namely the sacrifice of Christ, through which our final rejection of God and his Word was turned into his absolute forgiveness of our rebellion against him.

My own 'right-wing' Christianity tells me that there is not a single human being on earth who has not and who is not sinning against God. Sin against God is blasphemy. But Jesus taught us that there are degrees of blasphemy. All sins, $\mathrm{He}$ said, will be forgiven the sons of men, and whatever blasphemies they utter; but whoever blasphemes against the Holy Spirit never has forgiveness, but is guilty of an eternal sin (Mk 3: 28-29).

\section{THE ALTERNATIVE GOD OF LIBERATION THEOLOGY}

At this point I would like to turn to our liberation theology manifesto's. The Road to Damascus, referring to Jesus' words about blasphemy against the Holy Spirit, states: "Blasphemy also takes the form of "satanisation" - attributing the work of the Holy Spirit to the devil. Satanisation refuses to see the God of life in the liberation of the people' (Road 1990:18). This proposition can, and should of course, also be formulated contrariwise: It is equally a sin against the Holy Spirit to attribute the work of 
the evil spirit to the Holy Spirit. 8

Who is God for liberation theology as propounded by its South African manifesto's?

There can be no doubt whatsoever that this God is the destructive anti-god of Karl Marx. 9 Through 'social analysis', not through revelation, both God and the meaning of history are to be discovered.

This new source of revelation, namely social analysis, opens our eyes for the fact that this world is a scene of struggle between, on the one hand, the 'poor and oppressed' or 'the people' and, on the other hand, the rich and the powerful.10 The deepest meaning of history is to be understood as the dialectical process, manifesting itself as struggle and revolution, whereby the mighty are pulled down from their thrones and the lowly, that is the poor and oppressed, alias 'the people' are lifted up to reign.

There is a mystical union between God, on the one hand, and 'the people' (Marx's proletariat) on the other hand. So intense is this union that there remains, in fact, no line of distinction between the poor and oppressed 'people' and God. The central message of the Bible, namely the coming of the kingdom of God, is nothing other than a call to 'the people' or 'the poor' to dethrone the rulers of the world in order that they, the poor, may be enthroned as the new rulers - theirs is the reign of God. On the authority of the Gospel according to Luke, claims The Road to Damascus, the Reign of God means the reign of the poor and the oppressed, or 'the people'.

\section{An alternative Jesus}

Not only is God always on the side of the oppressed (Ps 103:6 - Jerusalem Bible), he is present in the poor and oppressed, like he was present in 'the poor Jesus' who was crucified, not as the Lamb of God who carries away the sins of the world, but because of his resistance against the Roman oppressors of his people and condemnation of the rich.

Adopting the image of the poor and joining them in their struggle to usurp the power of the rulers and the rich, he, Jesus, is the image of God, like the poor and oppressed, or 'the people' are the true image of God. In the awakening of 'the people' as the heirs to the throne of God, a 'new creation' is emerging. Jesus was the prefiguration of this new creation. Therefore, says The Road to Damascus, 'we want no gods except the God who was in Jesus'. 
No other gods except God the revolution

The God who was in Jesus was also the God who is in the people and who was the dynamic power of revolution which inspired Israel to stand up in rebellion against their Egyptian rulers in order to constitute themselves as a people of God. The rebel Jesus, the poor and oppressed, the people, the smouldering and exploding power of revolution - these are God. Listening to God means listening to this God: I am Yahweh your God who brought you out of the land of Egypt, out of the house of slavery,' says The Road to Damascus, referring to the power of revolution, and adds: 'You shall have no gods except me.'

Being an enemy of the people - and all who stand up in denial of the claim on behalf of the people, that is the poor and oppressed, that they are God incarnate, God's new creation with whom Jesus is to be identified and they with him, are its enemies - means ipso facto being an enemy of God.

The questions asked on the last page of The Road to Damascus are merely rhetorical: 'Who is God? Where is the true Jesus?' For the answer has been given throughout the pages of both The Kairos Document and The Road to Damascus: God is the deified proletariat and the deified dynamics of revolution against the status quo which should be awakened in them.

This God, being identified in the poor and oppressed and the power of revolution latent in them is, logically and naturally, his own saviour. Mobilisation of the people to take action and liberate themselves is his watchword and his command. Sin should be denounced and salvation should be announced. Denouncing sin would be of no avail if it only amounted to verbal judgements. It should be confrontational, so that the sinners may realise how dangerous and critical the kairos has become for them. No cover up will be possible, there will be no place to hide, no way of pretending to be what we are not.

Two social forces are in a life and death conflict with one another, the two eternal metaphysical powers are crossing swords: On the one hand the spirit of Marx (with socialism and people's power) representing God and, on the other hand, the spirit of traditional Christianity (with colonisation, exploitation, capitalism and oppression) representing the devil. These two cannot be reconciled.

\section{The enemy}

Traditional Christianity is the enemy par excellence. Nothing good can be attributed to it. It all started with the conversion of emperor Constantine to Christianity. Were it not for this fatal event, interpreted by traditional Christianity as the work of the Holy Spirit through which the doors were unlocked for the Christianisation of Europe, our liberationists want to make us believe that the sin against which they 
are declaring a holy war, would never have come over the world. 'In the hands of the ruling powers it (i e Christianity) became a weapon for legitimising the expansion of the empire, and, later, the colonisation of peoples,' so we are told in The Road to Damascus.

Christian missionaries who, during the period of colonisation took advantage of the opportunity to preach the gospel of Christ 'to the end of the earth' and to 'make disciples of all nations' were, in fact, emissaries of the devil. The cross which they preached 'blessed the sword which was responsible for the shedding of our people's blood. The sword imposed the faith and protected the churches, sharing power and wealth with them' (Road 1990:1). The missionaries preached a false God, because He 'demanded resignation in the face of oppression and condemned rebelliousness and insubordination'. ${ }^{11}$ Likewise, the Christ of this God was a false Christ because 'He condescended to make the poor the objects of his mercy and compassion without sharing their oppression and their struggles'.

\section{God the People}

The traditional doctrine of guilt and the reconciliation of guilt through the unique sacrifice of Jesus, the eternal Son of God, should be brushed aside with contempt, because in the traditional doctrine 'His death had nothing to do with historical conflicts, but was a human sacrifice to placate an angry God' (Road 1990:2).

Liberation theology wants, therefore, another God and another Jesus who have 'relevance to this life'. It is the angry people who demand placation. Their God is one whose essence is rebelliousness and insubordination, who incarnates himself in the struggle of the people, who is the deified people taking now responsibility for their own liberation.

One of the first converts to this 'new faith' was the apostle Paul. The apostle's conversion was one from siding with the authorities and the status quo to 'this new movement that worked to "turn the world upside down" (Ac 7:58; 8:1)' which is now embodied in 'the people'. It was the voice of 'the people' that came to him on the road to Damascus: 'Saul, Saul, why do you persecute me? Who are you Lord? I am Jesus whom you are persecuting'. 'Saul became Paul when he accepted in faith that the true god was in Jesus and that the risen Lord was in the very people whom he had been persecuting' (Road 1990:12). Paul's conversion to the true God and the true Jesus was in fact a conversion to the numinous power of rebelliousness and insubordination personified in 'the people'.

The 'people-God', (I prefer to call it 'God the people') who was also present in Jesus and Stephen, took possession of Paul and he joined the ranks of those struggling against the Temple and the Law as their greatest enemies - the Temple being 
not only the centre of religious power but also of political and economic power, and the Law being the guarantee of the status quo.

Throughout the centuries, the nature and object of the struggle of 'God the People' have not changed'. 'God the People' know who its enemies are. The sinners and their sins can be identified accurately. Most important among those are historical Christianity; the Christian missionaries with their idolatry; colonialism which perpetuate itself in the economic 'imperialism' of the West' that is the USA, Japan and Western Europe, pumping billions of dollars for development aid into the Third World; the money which the rich have (Mammon) but which in fact belong to the poor;12 international capitalism and anti-communism; national security and the power, privileges and pleasure of the rich; the state and its authority; the Bible and its authority; right-wing Christianity and its condemnation of liberation theology; all those who condemn God the people's use of arms against any form of what they (or it) experience as 'oppression'. These are but a few, but important examples of the enemies who are to be crushed.

\section{God the Spirit of destruction}

On the other hand, the enthronement of God the People calls for a new morality and a new strategy. Communism is morality, and all opposition to it is idolatry (or ideology). ${ }^{13}$ No reconciliation is possible between God the People and the evil of capitalism, or for that matter, between 'the justice of reform' which is supposed to come 'from people who are at the top of the pile' and justice 'that comes from below and is determined by the people'. The only conceivable justice is that of God the people alias God the Oppressed. 'True justice, God's justice', claims The Kairos Document, 'can only come from below, from the oppressed themselves' (Kairos 1986:11-12).

The new morality of the new God demands that whatever means are used for his enthronement, whether it be 'throwing stones, burning cars and buildings and sometimes killing collaborators', or even the 'armed struggle' as such should not be called 'violence'. It is the 'wicked oppressor' who is committing violence. God the Oppressed, in the process of ascending his throne, plants bombs, kills, burns cars, necklaces people, doing this all in complete innocence, defending his cause which is justified from all eternity (Kairos 1986:13, 24).

This is the way in which he displays his love for his enemies. ${ }^{14}$ The most loving thing he can do both for himself ( $i$ e the people or the oppressed) and his enemies is to eliminate them, to remove the tyrants from their power "by means of boycotts, strikes, uprisings, burnings and even armed struggle' (Kairos 1986:24). 
The sacraments and the Church of God the Revolution

'God the People' or 'God the Oppressed' can also be called 'God the Revolution'. It is in his name that 'solidarity' should be celebrated at his holy Table. 'It is', says The Kairos Document, 'the solidarity of the people inviting all to join in the (armed?) struggle for God's peace in South Africa'.

The most outstanding characteristic of the Church by which it is to be known as the true Church, is its dedication to the struggle of 'God the Oppressed' and its identification with it. There is no other God, and the boundaries of his Church are much wider than those of the official Church. For this reason, says The Kairos Document, 'the Church's programmes and campaigns must not duplicate what the people's organisations are already doing and, more seriously, the Church must not confuse the issue by having programmes that run counter to the struggles of those organisations that truly represent the grievances and demands of the people' (Kairos 1986:29).

After all, God is the people and the people is God, and the Church who is a servant of God the people should heed the voice of the people. Vox populi vox Dei. The people cannot be wrong (Kairos 1986:23). They are in the majority over against the capitalist minority. In order to be truly 'biblical' the Church must take sides with the majority. 'In order to be truly biblical', states The Kairos Document, 'our Church leaders must adopt a theology that millions of Christians have already adopted' (Kairos 1986:11) - which is the theology of God the Revolution or in (my) other words, the destructive anti-God of Karl Marx.

\section{THEOLOGY OR SATANOLOGY?}

In liberation theology, we have indeed the radical alternative of theology as reflection on God. It is the antipode thereof. It is a 'theology' of destruction. And as such it is satanology - under the guise of theology.

In so far as it operates with the concept of a trinitarian God, its trinity stands in an inimical and irreconcilable opposition to the traditional belief in God the Father and Creator, God the Son and Redeemer and God the Spirit and Recreator.

Its 'God the Father' is God the Revolution and Destroyer; its 'God the Son' is God the People in whom God the Revolution became, and is becoming incarnate; its 'God the Spirit' is the evil and destructive Spirit of Karl Marx.15

Both The Kairos Document and The Road to Damascus, the two manifesto's of liberation theology in South Africa, are declarations of a ruthless war against orthodoxy, in fact, against the Bible itself and against Christian faith as such. 
The reason why the propagators of the Marxist revolution, which includes a destructive fury against God, religion, Christianity and ultimately the world as such, took recourse to the Bible, is not difficult to guess. Marx himself could never detach his own philosophy from the Bible and biblical patterns of thought.

Despite his dependence on the Bible, however, he would never have dreamt of theologising in such a blatant way, making such extensive use of biblical texts in order to hammer home his message. Why then, do his followers do it with such glee and sadistic pleasure? The answer, in my opinion, lies in the simple philosophy of: 'If you can't beat them, join them.' If devil can cite Scripture for his purpose, why not his followers and those of Marx? And indeed, it is highly effective.

Liberation theology is the theology of the masses. Like all fakes (of genuine works of art) for instance, it caters for the market of mass-consumption. However, it is a Satanic deception and, therefore, short-lived. Upon it rests the annihilating judgement of God. It cannot stand before him.

\section{GOD AND MARX}

God, who is also the God and Redeemer of the poor and the oppressed, is not the destroyer of this world.

Karl Marx was not his disciple, but his hater and enemy. God does not hate himself, neither does he hate his creation. The world to come will not be a nova creatio leaving behind the ashes of God's creation: it will be the recreation of this creation, to which its Maker remains faithful in all eternity.

Liberation theology must be rejected as hubris and arrogance. It is alien to God, alien to his work of salvation and alien to the world which is to be saves necessarily and essentially alien because it breathes the self-alienated, worldalienated and God-alienated spirit of Karl Marx.

This is the reason why it became so urgent to call for the restoration of orthodoxy, with God affirmation, self-affirmation and world-affirmation as its biblical legitimation, in South African Christian theology.

Only orthodox theology is truly 'this-worldly' theology. The Marxist gospel, preached so fervently by our liberationists, has no eschatology for this world. All it can offer is a utopia. And the utopia is an ov́ tóros, a 'no-place', a nowhere - unless the chaos created by Marxism can be called 'a somewhere'.

\section{Endnotes}

1 Jürgen Moltmann advocates the use of the basic doctrines of Marx as a herme- 
neutical key to the understanding of the Bible (Moltmann 1974:passim).

2 A Nolan (1987:1) says about The Kairos Document: 'I am delighted to see that theology has at long last been put on the agenda in South Africa'.

3 Road (1990:13ff) rejects 'right-wing' Christianity, including 'anti-communist' theology, as heretical.

4 Cf Künzli (1966:168): 'Dominierend waren in dieser Seele (i e that of Marx) die sich ihres "dämonischen Abgrunds" dunkel bewusst war, der Trotz und der Hohn, Neid, Rache, Hass, Verachtung, der Trieb zu Destruktion und Selbstvernichtung, aber auch zur Neuschöpfung der Welt aus sich selbst heraus, gepaart mit einem unverhüllten Willen zur Macht und Selbstvergottung.'

5 Elevating Prometheus to the status of 'der vornehmste Heilige und Martyrer im Philosophischen Kalender', Marx rejected all 'gods', stating 'Mit schlichtem Wort, den Göttern allen heg' ich Hass', which is 'der Philosophie eigenes Bekenntnis' in philosophy's struggle 'gegen alle himmlische und irdischen Götter, die das menschlichen Selbstbewusstsein nicht als die oberste Gottheit anerkennen. Es soll keiner neben ihm sein' (MEGA I 1/1 10). Künzli (1966: 532) states: 'Da Marx die Existenz von Tranzendentem nicht mehr anerkannte, musste Gott, der Weltschöpfer, auf dieser Erde zu finden sein: Es war der prometheische Mensch mit seinem vergöttlichten Selbstbewusstsein, der auf geheimnisvolle weise mit Hilfe seiner Arbeit sein eigener Schöpfer geworden war.'

6 Helmut Gollwitzer remarks in this regard: 'Durch eine so reduzierte Sicht des Bösen - rational erklärt aus den aüsseren Lebensbedingungen und reduziert auf den Besitztrieb, also indentifiziert mit der Asozialen - kann die Illusion entstehen, dass es sich durch sozialer Veränderungen beseitigen liesse. Und umgekehrt: die absolute Bewertung der Bedeutung sozialer Veränderungen verlange eine reduzierte Sicht des Bösen. Für die christliche Sicht ist das Böse nicht rational erklärbar, die alte Philosophenfrage des unde malum nicht theoretisch beantwortbar' (Gollwitzer 1965:100ff).

7 'Die Welt soll aus mir selbst entsteigen', stated Marx in an early poem (MEGA I 1/2 26). Man must 'aus eigenen Mitteln die ganze Welt...bauen, Weltschöpfer...sein' (MEGA I 1/1 122).

8 Karl Marx also used the biblical term 'sin against the Holy Spirit', however, like our liberationists, with reference to capitalism and the 'doctrine' of private ownership: 'Dieser verworfene Materialismus, diese Sünde gegen die heiligen Geist der Völker und die Menschheit ist eine unmittelbare Konsequenz jener Lehre...' (MEW 1 1961:147).

9 Marx's veneration of Prometheus sheds some light on what is meant by his 
'God'. Künzli (1966:631), observes: 'So fand Karl Marx durch Prometheus selbst seine Affekte und damit nicht nur seinen Drang zur Weltschöpfung, sondern auch seine mächtigen Destruktionstreib, aber auch seinen Willen zur Macht zur Selbstvergottung...bestätigt.'

10 It is not the Bible, which draws the decisive line of distinction between the poor and oppressed as the people of God on the one hand, and the oppressors and the rich as the instruments of evil, on the, other hand, but Marx; cf MEW 5 (1961:133), where Marx, for the first time (in 1848) divided the French Nation into two nations, 'die Nation der Besitzer und die Nation der Arbeiter'. His deepest concern was 'ein Sieg der französischen Arbeiters über den französichen Kapitalisten' (MEW 17 1961:319).

11 This view echoes Karl Marx: 'So ist der Herrschaft der Religion nichts anderes als die Religion der Herschaft, der Kultus der Regierungswillens' (cf MEW 1 1961:101).

12 In Künzli's observation that Marx, the archenemy of 'Mammon', 'überhaupt keine Beziehung zum Geld hatte, ausser derjenigen, das Geld auszugeben, das andere verdient hatten' we recognise a prefiguration of what the liberation theologians want to be the attitude to Third World countries to the 'staggering size of (their) Third World debt'. In the 'Reign of God', which is the Reign of the Poor, it will be 'Jubilee year': '...all debts will be cancelled and the land will be restored to those from whom it was stolen' (Künzli 1966:581ff and Road 1990:2, 8).

13 Cf Denys Turner: 'Marx did found a new science of society - indeed, the only science of society...religion and morality are ideological' (Turner 1983:4). Ideology, according to Turner, 'is a species of lived, or performative contradiction' (Turner 1983:35), or 'a society's false consciousness of itself. It seems to be in line with liberation theology's view of traditional Christianity.

14 Liberation theology claims to announce liberation to both the oppressed and their oppressors. Karl Marx also proclaimed a comprehensive salvation for the whole world: 'Aus dem Verhältnis der entfremdeten Arbeit zum Privateigentum folgt ferner, dass die Emanzipation der Gesellschaft vom Privateigentum etc, von der Knechtschaft, in der politischen Form der Arbeiteremanzipation sich ausspricht...weil im ihrer Emanzipation die allgemein menschliche erhalten ist, diese ist aber darin erhalten, weil die ganze menschliche Knechtschaft in dem Verhältnis des Arbeiters zur Produktion involviert ist und alle Knechtschafsverhältnisse nur Modifikationen und Konsequenzen dieses Verhältnisses sind' (MEPM 1844:110; cf also MDK I 1961:754).

15 Marx, following the example of Hegel, discovered 'the holy Trinity' in his own 
'dialectic' which necessarily ensues in revolution. 'Der "Begriff" ist der Sohn in der "Idee", dem Gott Vater, das agens, das determinierende, unterscheidende Prinzip'. God the Father is the 'determining principle', i e of revolution and God the Son is the 'concept', i e of materialism which for Marx is the material relationship between landowners and labourers (MEW 1 1961:213). True critique which, for Marx, is a critique of creation as such - 'der rücksichtslose Kritik alles Bestehenden' leads to 'die innere Genesis der heiligen Dreieinigkeit im menschlichen Gehirn' (MEW 1961:296).

\section{Works cited}

Engelbrecht, B 1978. God en die politiek. Durban: Butterworth.

Gollwitzer, H 1962. Die marxistische Religionskritik und der christliche Glaube. München: Siebenstern.

Kunzli, A 1966. Karl Marx: Eine Psychographie. Wien: Europa.

Marx, K 1961. Das Kapital, vol I. Berlin: Dietz. (abbreviated as MDK 1961).

Marx/Engels 1955. Kleine ökonomische Schriften. Berlin: Dietz. (Pariser Manuskripte von 1844, I. Abbreviated as MEPM 1844.)

Marx/Engels, 1961. Werke. Berlin: Dietz. (Abbreviated as MEW 1961).

Marx/Engels 1927-1935. Historisch-kritische Gesamtausgabe. Frankfurt: Insel. (Abbreviated as MEGA.)

Moltmann, J 1974. The crucified God. London: SCM.

Nolan, A 1987. Lectures on the Theology of Liberation. Hilton: Order of Preachers.

The Kairos Document 1986. Johannesburg: Skotaville. (Abbreviated as Kairos 1986.)

The Road to Damascus 1990. Johannesburg: Skotaville. (Abbreviated as Road 1990.)

Turner, D 1983. Marxism and Christianity. Oxford: Blackwell. 